\title{
Communication Skill Development for Rural Adolescents through Social Cognitive Intervention
}

\author{
Dr S Gayatridevi ${ }^{1}$, Prof. Dr. A. Velayudhan ${ }^{2}$, Palanisamy. $\mathbf{V}^{3}$ \\ ${ }^{1}$ Associate Professor and Head in Psychology, Avinashilingam Institute for Home Science and \\ Higher Education for Women, Coimbatore 641043 \\ ${ }^{2}$ Professor, Department of Psychology, Bharathiar University, Coimbatore-46. \\ ${ }^{3}$ Ph.D scholar, Department of Psychology, Bharathiar University, Coimbatore-46 \\ Email:_rgaya1965@gmail.com,avelayudham@rediffmail.com,palanisamyv8@gmail.com
}

\begin{abstract}
Communication skills are playing an important role in predicting individual's employability in work place. Youth from the rural area are not equipped with the communication and public speaking skills therefore they are struggling to get into the job market. According to social cognitive theory and Vygotsky's theory of cognitive development individual's immediate society and family are the major influencing factors of skill acquisition. Youth from such environmental conditions are requiring skill development trainings. The objective of the current study is to examine the effectiveness of social cognitive intervention on communication skills development among the rural adolescents. $11^{\text {th }}$ grade Students from government school located in rural area of Coimbatore district were selected, totally 50 students participated in this study. Purposive sampling method was used to select the sample. Single group Pre-test, post-test and follow up experimental design was used. The study consists with four phases 1) pre-test phase 2) Intervention phase (social leaning intervention) 3) Post-test phase and 4) follow up Phase. The intervention session was conducted weekly once to the participants in 12 sessions for duration of three months period. Mean, SD, ANOVA, Post hoc tests were used to analyze the data. Results revealed that social learning intervention significantly improved the rural students' communication skills.
\end{abstract}

Keywords: Social Cognitive Intervention, Communication Skills, Rural Adolescents, Employability.

\section{INTRODUCTION}

Unemployment and underemployment is the mounting challenge for India. Parents dream is that admitting their son/daughter in attractive educational institution will make their children as a successful person in work life and life. Most of the educational institutes including arts and science, engineering colleges and universities are keenly searing for the solution to make competent young Indian employees to the job market, unfortunately these institutes failed to include some important predicting factors of employability such as psychosocial influences. On the other hand position of students from rural area is vulnerable in the modern job market. Finally most of the Indian graduates are remaining unemployed or underemployed (National Employability Report of Engineering Graduates, 2014, FICCI, 2012). In the process of making skilled employees psychology plays crucial role such as identifying the inhibiting causes of skill acquisition and developing skill through the psychological interventions. Students from rural area are not taking effort to develop their personal skills. Velayudhan and Palanisamy (2015) revealed that rural college students believe that merely degree from the colleges will help to obtain the desirable job regardless of their social skills. Rural student's Social context, and parent's skill and knowledge are not adequate to acquire the requiring skills. Individual's environment and adult support are the important elements in social skills development (Bandura, 1989., Vygotsky, 1978., \& Spence,1995). Development of social skills in children is influenced by many factors such as inheritance, environment, 
culture, attitudes and behaviors of parents, relations with siblings and peers, behaviors of teachers and training programs (Ceylan, 2009; Önalan AkfÕrat, 2006).

\section{SOCIAL SKILLS AND EMPLOYABILITY}

Yorke, (2004) gave the following definition for employability, a set of achievements - skills, understandings and personal attributes that make graduates more likely to gain employment and be successful in their chosen occupations, which benefits themselves, the workforce, the community and the economy. Employability consists with many skills including technical skill and social skills or generic skills. Social skills include leadership skills, interpersonal skills, intrapersonal skill, critical thinking, problem solving and communication skills (Rasul., et al., 2013). Organizations recommend educational institutions to focus on developing social skills in the students (Sermsuk., 2014). Many findings show that social skills are major predictor of employability. Inadequate social skill leads to unemployment. There are two types of deficits which is acquisition deficit and performance deficit. Acquisition deficit is lack of exposure and fewer resources from the individual's environment, family, and school. Diversity in social practices produces substantial individual differences in the capabilities that are cultivated and those that remain underdeveloped. On the other hand performance deficit means individuals who knew necessary social skills at the same time inability to use those skills (Spence,1995). Hence the social skill is highly important to improve the individuals employability, finding the appropriate training method to develop those skills are immediate need. Therefore in this study effectiveness of social cognitive intervention was used to assess whether this intervention will improve the communication skills among rural adolescents.

\section{COMMUNICATION SKILLS}

Employers expecting employee with great communication skills who communicate their personal thought and idea with others in the organizations, and improve team work effectiveness. Communication skills lead individuals to express their needs more and efficiently and help them to understand the needs of others and also benefit more of mental health. Communication skills training programs in schools can have positive effects on the future lives of youth (Vatankhah, 2013). Enhancing rural adolescents communication skills help to improve their employability. Rural student's behavior and skill development is influenced by their immediate social environment therefore social cognitive intervention was used to develop student's communication skills in the present study.

\section{SOCIAL COGNITIVE THEORY}

Social cognitive intervention was developed based on Bandura's Social cognitive theory and Vygotsky's social developmental theory. Bandura (1989) proposed the model called reciprocal determinism. In this model behavior, cognition and other personal factors, and environmental influences all operate as interacting determinants that influence each other bidirectionally. He also argued that each elements of reciprocal determinism does not influence behavior equally, some may be stronger than others. During the early years of life changes occur rapidly. People process and transform passing experiences by means of verbal, imaginal and other symbols into cognitive models of reality that serve as guides for judgment and action. Guided instruction from others, verbal reinforcement and observing others behavior effectively influence cognitive development of the children (Bandura, 1986). Socially guided learning will encourage children to act self-directionally for dealing intelligently with difficult situations in future (Rosenthal \& Zimmerman, 1978).

According to Vygotsky (1978) in the classroom teachers have to provide space for peer instruction, collaboration, and small group instruction. Vygotsky believes that development is a lifelong process and social interaction is the major factor which predicts the individual's cognitive development. He called this process as "Zone of Proximal Development" in this process he argued that potential development takes place by adult guidance and collaboration with skilled peers.

Self modeling video intervention has improved the behavior and academic participation of the school students (Hitchcock, 2003). Modeling behavior significantly improved the basic life skills of adolescents with developmental disorder (Gardner, and Wolfe., 2015). Schlichting (2004) reveled that self-modeling video intervention significantly reduced the public speaking anxiety of school students. 


\section{METHOD}

\section{Objective}

To find out the effectiveness of social cognitive intervention among rural adolescent's communication skills development.

\section{Hypotheses}

1. Rural students' communication skill got improved after the social cognitive intervention.

1.1. Rural students' luck control skill got improved after social cognitive intervention.

1.2. Rural students social control skill got improved after social cognitive intervention.

\section{Sample}

1.3. Rural students' self-control skill improved after the social learning intervention.

$11^{\text {th }}$ grade rural students were selected from the Government Higher Secondary School located in rural area of Coimbatore district in Tamil Nadu, 50 students participated. The purposive sampling method was used to select sample. Purpose of the research was explained to the school principal and parents.

\section{Inclusion criteria}

$>$ First generation school students

$>$ Students from poverty and below poverty line

$>$ Students from Scheduled caste (SC) and Scheduled tribe (ST) Other backward Class (OBC).

$>$ Students from rural area and hills station.

$>$ Government school students

\section{Conceptual frame work}

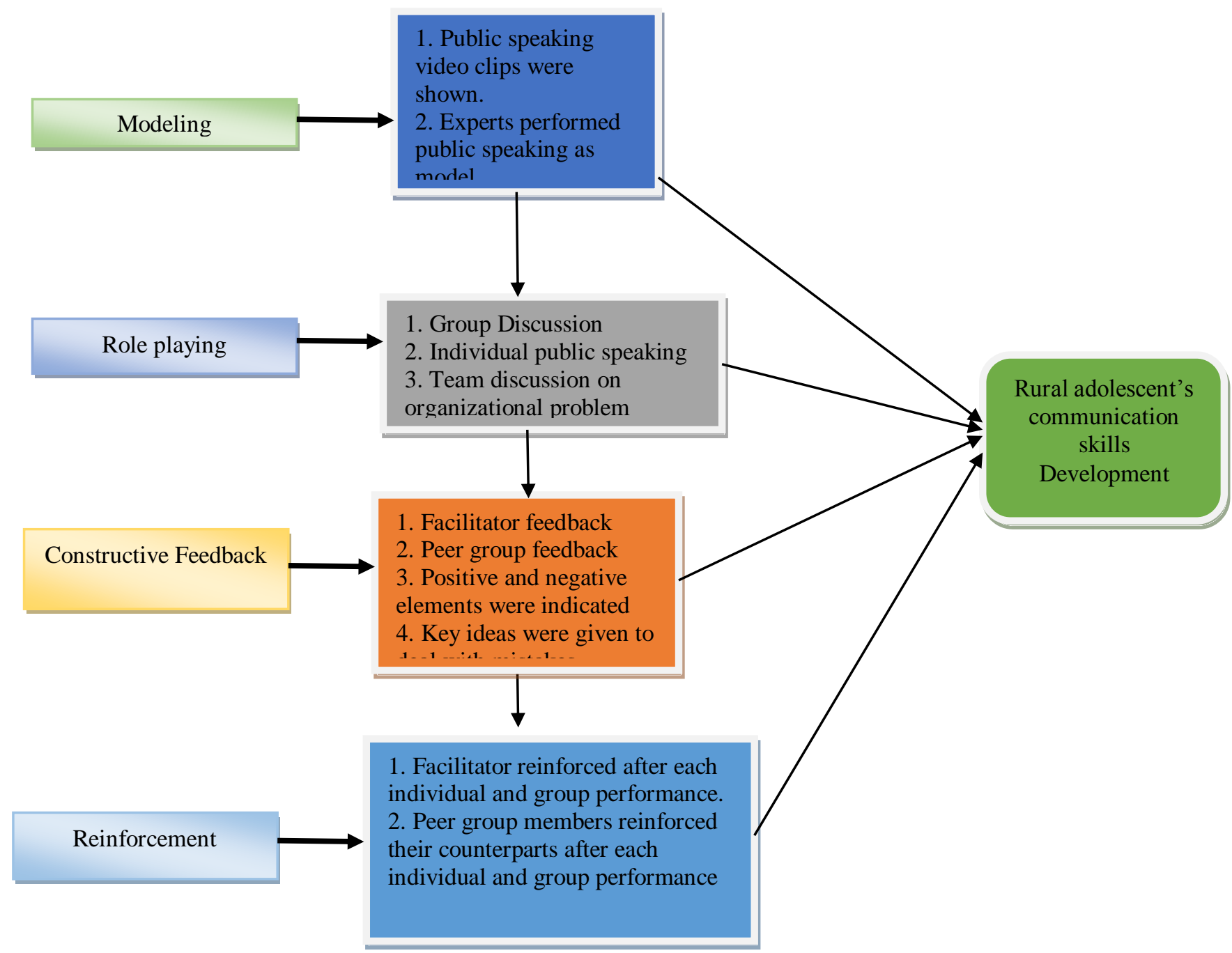

Figure 1 shows the influence of social cognitive intervention on rural adolescent's communication skills development. 


\section{Exclusion criteria \\ $>$ Those who have studied in private schools prior to the current school \\ $>$ Students from above poverty line \\ $>$ Students those are having educated parents \\ $>$ Students already had exposure with similar Training programs.}

\section{Communication skills}

Communication locus of control is individual's general feelings about public speaking in particular and communication in general.

- Luck: Individual's ability to control belief toward luck during public speaking or conversation.

- Social System Control: individual's level of contribution in communication/ conversation situation in public speaking apart from social influence.

- Self-Control: Individuals' ability to manage social anxiety and maintain personal wits in public speaking.

\section{Tools}

\section{Communication Locus of Control Scale (CLCS), Hamilton (1991).}

Communication locus of control scale is used to assess the students' public speaking and communication skills include three dimensions luck control, social control, self-control. CLCS is a 17 item scale with four point Likert scale was used to respond to the items as 1 . Strongly disagree with the statement, 2. Disagree with the statement, 3. Agree with the statement, 4. Strongly agree with the statement.

\section{Research Design}

Single group Pre-test, Post-test, and follow up experimental method was used to identify the effectiveness of the social cognitive intervention.
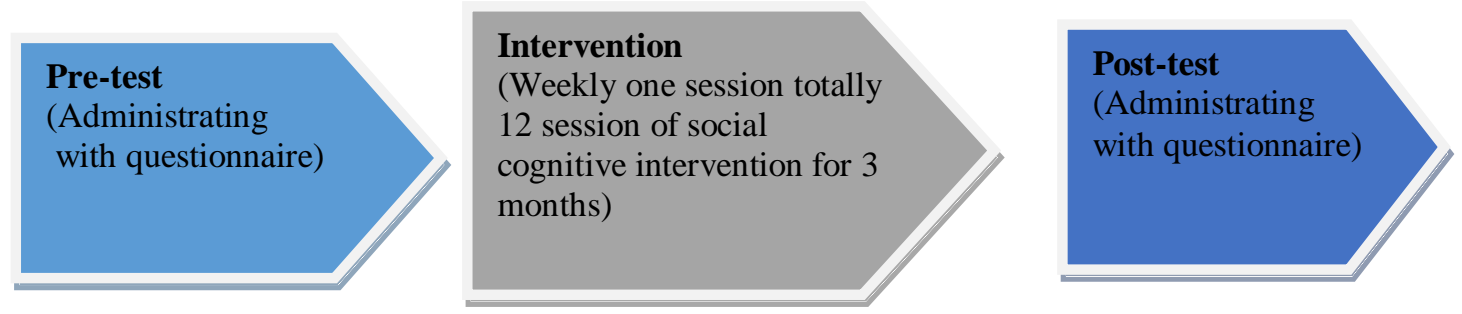
Follow up
After three months (Administrating with questionnaire)

Figure 2 shows the four phases of the study

\section{Statistics}

Mean, SD, ANOVA, Post hoc tests were used to analyze the data. SPSS 16 software was used to process the data.

\section{Results and discussion}

Table 1: Demographic Characteristics of Rural Adolescents

\begin{tabular}{|c|c|c|}
\hline Characteristics & $\mathrm{N}$ & $\%$ \\
\hline \multicolumn{3}{|l|}{ Age } \\
\hline 16.0 & 24 & 48 \\
\hline 17.0 & 25 & 50 \\
\hline 18.0 & 1 & 2 \\
\hline \multicolumn{3}{|l|}{ Major Subject } \\
\hline Arts & 29 & 58 \\
\hline Science & 21 & 42 \\
\hline \multicolumn{3}{|l|}{ Community } \\
\hline Scheduled Caste (SC) & 16 & 32 \\
\hline Scheduled Tribes (ST) & 2 & 4 \\
\hline Other Backward Castes (OBC) & 32 & 64 \\
\hline
\end{tabular}




\begin{tabular}{|c|c|c|}
\hline Father's Occupation & & \\
\hline Daily Wage & 43 & 86 \\
\hline Private factory Employee & 3 & 6 \\
\hline Small Scale Entrepreneurs & 4 & 8 \\
\hline \multicolumn{3}{|l|}{ Mother's Occupation } \\
\hline Daily Wage & 32 & 64 \\
\hline Private factory Employee & 4 & 8 \\
\hline Small Scale Entrepreneurs & 1 & 2 \\
\hline House Wife & 13 & 26 \\
\hline \multicolumn{3}{|l|}{ Living Area } \\
\hline Rural & 39 & 78 \\
\hline Tribal Village & 2 & 4 \\
\hline Hills station & 9 & 18 \\
\hline
\end{tabular}

Table 2 Mean and SD of pre-test, post-test and follow-up in Communication locus of control of rural adolescents.

\begin{tabular}{|c|c|c|c|c|c|c|c|}
\hline $\begin{array}{l}\text { Communication } \\
\text { locus of control }\end{array}$ & N & \multicolumn{2}{|c|}{ Pre-test } & \multicolumn{2}{c|}{ Post-test } & \multicolumn{2}{c|}{ Follow Up } \\
\hline & & Mean & SD & Mean & SD & Mean & SD \\
\hline Luck control & 50 & 2.50 & .52 & 3.51 & .47 & 3.76 & .37 \\
\hline Social control & 50 & 2.52 & .46 & 3.25 & .46 & 3.69 & .27 \\
\hline Self-control & 50 & 2.52 & .50 & 3.36 & .44 & 3.34 & .39 \\
\hline
\end{tabular}

Table 3 F Value for Pre-Test, Post-Test and Follow-Up in Communication Locus of Control among the rural Adolescents.

\begin{tabular}{|c|c|c|c|c|c|c|}
\hline $\begin{array}{c}\text { Source of } \\
\text { variation }\end{array}$ & Variable & $\begin{array}{c}\text { Type III } \\
\text { Sum of } \\
\text { Squares }\end{array}$ & df & $\begin{array}{c}\text { Mean } \\
\text { Square }\end{array}$ & F & Sig. \\
\hline $\begin{array}{c}\text { Within group } \\
\text { variance }\end{array}$ & $\begin{array}{c}\text { Luck } \\
\text { Control }\end{array}$ & 44.756 & 1.971 & 22.707 & 133.795 & .000 \\
\cline { 2 - 7 } & $\begin{array}{c}\text { Social } \\
\text { control }\end{array}$ & 34.887 & 1.719 & 20.292 & 128.436 & .000 \\
\cline { 2 - 8 } & self-control & 23.012 & 1.767 & 13.026 & 106.212 & .000 \\
\hline Error & $\begin{array}{c}\text { Luck } \\
\text { Control }\end{array}$ & 16.39 & 96.57 & 0.17 & & \\
\cline { 2 - 8 } & $\begin{array}{c}\text { Social } \\
\text { control }\end{array}$ & 13.31 & 84.24 & .15 & & \\
\cline { 2 - 8 } & self-control & 10.61 & 86.56 & .12 & & \\
\hline
\end{tabular}

Table 4 Post-Hoc test for Pre-test, Post-test and Follow up in Communication Locus of Control among the Rural Adolescents.

\begin{tabular}{|c|c|c|c|c|}
\hline $\begin{array}{c}\text { Communication } \\
\text { Locus of control }\end{array}$ & Phase(I) & Phase(J) & MD & Sig \\
\hline Luck Control & Pre-test & Post-test & 1.01 & $* *$ \\
\cline { 3 - 5 } & & Follow-up & 1.26 & $* *$ \\
\hline
\end{tabular}




\begin{tabular}{|c|c|c|c|c|}
\hline & Post-test & Follow-up & 0.25 & $* *$ \\
\hline \multirow{3}{*}{ Social control } & \multirow{2}{*}{ Pre-test } & Post-test & 0.72 & $* *$ \\
\cline { 3 - 5 } & & Follow-up & 1.17 & $* *$ \\
\cline { 2 - 5 } & Post-test & Follow-up & 0.44 & $* *$ \\
\hline \multirow{2}{*}{ self-control } & Pre-test & Post-test & 0.84 & $* *$ \\
\cline { 2 - 5 } & & Follow-up & 0.82 & $* *$ \\
\cline { 2 - 5 } & Post-test & Follow-up & 0.02 & NS \\
\cline { 2 - 4 } & \multicolumn{2}{|l}{} & & \\
\hline
\end{tabular}

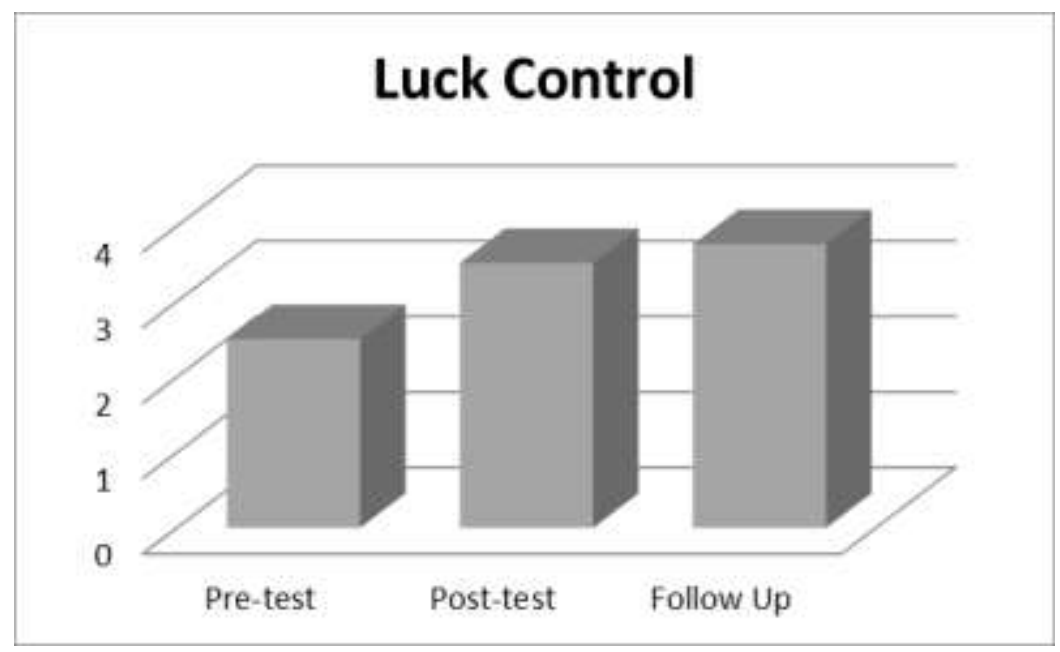

Figure 3 shows the mean difference of luck control between the pre-test, post-test and follow up test

\section{Social Control}

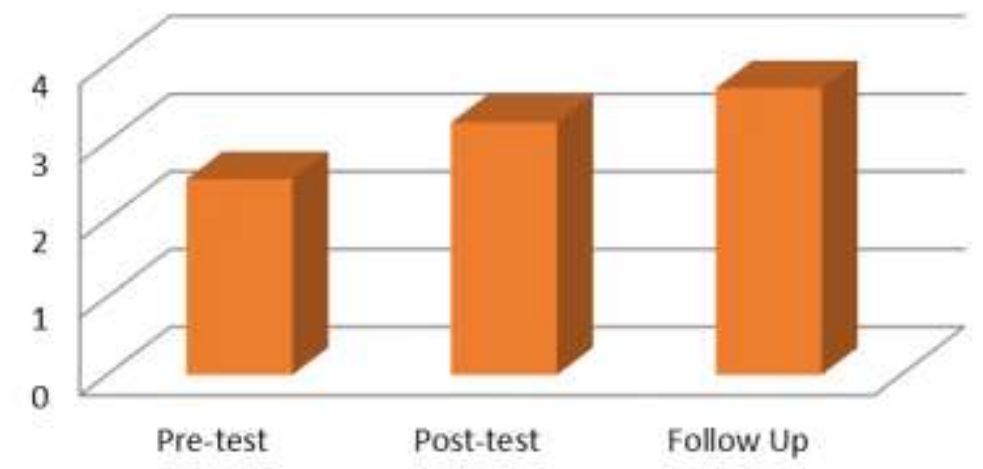

Figure 4 shows the mean difference of social control between the pre-test, post-test and follow up test.

Table 2 shows the mean and SD of communication locus of control in pre-test, post-test, and follow up tests. Table 3 shows the $F$ value of the communication locus of control skills in pre-test, post-test, and follow up tests.

\section{Self-Control}

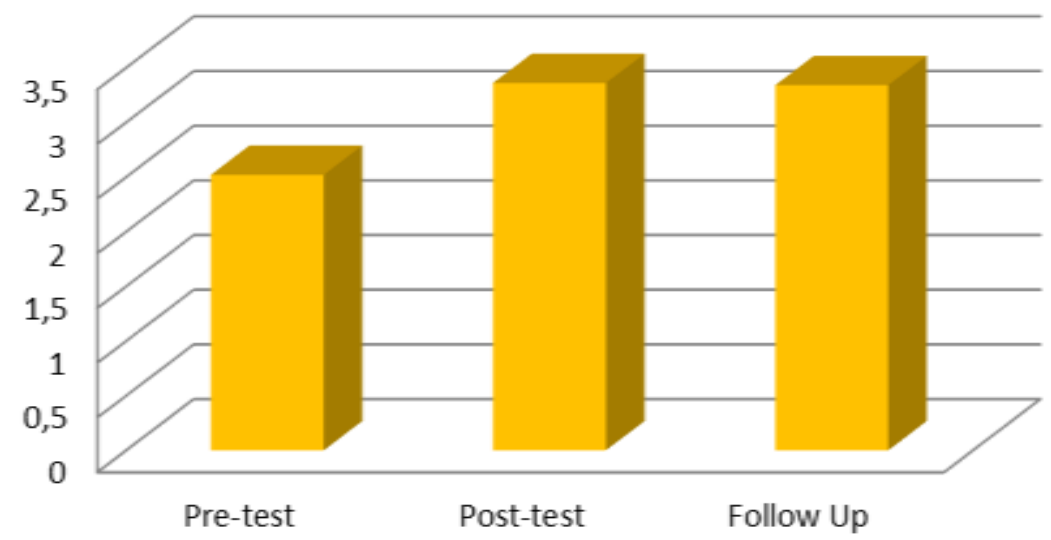


Table 4 shows the Post-Hoc analysis results of communication locus of control dimensions. The difference between pre-test and post-test was found to be significant $(M D=1.01, p=.000)$ in luck control dimension. Similarly pre-test and follow up test was found to be significant $(M D=1.26, p=000)$. Likewise difference between post-test and follow up test was also found to be significant $(M D=.25, p=.000)$. It shows that students luck control has improved after the intervention which indicated that their belief of luck is reduced. Intervention helped them to understand the actual causes that influence public speaking. During the feedback session facilitator explained that luck has no role in making a good speech. Various skills and knowledge help individuals to deliver a good speech. Participants also had a discussion regarding role of luck in speaking at the concluding session of the discussion, all the participants agreed and learnt that luck has no role to play in public speaking.

In social control dimension of table 4 the difference between pre-test and post-test was found to be significant $(M D=.72, p=.000)$. Similarly pre-test and follow up test results was significantly different $(M D=1.17, p=.000)$. Significant difference $(M D=.44, p=.000)$ was found between the post-test and follow up in social control dimension. Results revealed that social cognitive intervention helped rural students to control social pressure during the public speaking. During the modeling session speaking expert performed a special public speaking in which techniques include controlling the audience pressure on individual speaking. During the group discussion session facilitator assigned a distracter for each group, the role of distracter was to make disturbances during the conversation and facilitator observed each group to examine whether group member dealt the distracter effectively or not, based on the observation the facilitator gave feedback to make changes in dealing with styles. Facilitator also reinforced the students when they handled the social pressure during the communication.

In Table 7 the post-hoc test results shows that difference between the pre-test and post-test was found to be significant $(\mathrm{MD}=.84, \mathrm{p}=.000)$ and difference between the pre-test and follow up test also found to be significant $(\mathrm{MD}=.82, \mathrm{p}=.000)$. Difference between the post test and follow up test was not significant $(\mathrm{MD}=.02, \mathrm{p}=\mathrm{NS})$. The results show that social cognitive intervention has helped rural students to improve the self-control skills during the public speaking. During the social cognitive intervention in modeling session facilitator had a public specking demonstration then methods and techniques was explained to the participants to understand the way of controlling themselves in terms of confusion, fear, and tension during the public speaking. According to the Hancock et al (2008) giving direct instruction and feedback improved the public speaking skills and peer group discussion, public speaking practice in class room setting also significantly improved the students' communication skills. Lau and Wang (2013) revealed that students centered approaches such as focus group discussion; peer feedback significantly improved the student's communication skills. Saidalvi and Mansor (2012) found that watching public speaking videos as a model, practicing public speaking and receiving feedback about their speaking skills from their peer group have effectively enhanced the public speaking ability of the college students.

\section{CONCLUSIONS}

Rural students had gained their communication skills after Social cognitive intervention. Social cognitive intervention significantly improved the luck control of the rural students during public speaking. Social cognitive intervention significantly improved the social control of the rural students during public speaking. Social cognitive intervention significantly improved the self-control of the rural students during public speaking.

\section{Implications}

$>$ Government and policy makers can institute the social cognitive intervention in all the Government schools were large number of rural students are studying.

$>$ School teachers can include the social cognitive techniques during the class to enhance the student's behavior and effective class room participation.

NGO's working in rural youth skill development can include social cognitive techniques to improve the students' employability skills. 


\section{REFERENCES}

1. Bandura, A. (1989). Social cognitive theory. In R. Vasta (Ed.), Annals of child development. Vol. 6. Six theories of child development (pp. 1-60). Greenwich, CT: JAI Press.

2. Ceylan, ù. (2009). VÕneland Validity-Reliability Study for Social-Emotional Early Childhood Scale and Examination of the Influence of Creative Drama on Five-years old Children's Social-Emotional Behaviors who have been attending to the Preschool Training Institutions. Unpublished Doctorate Thesis. Gazi University, Institute for Educational Sciences. Ankara.

3. Gardner, S. J. (2015). Teaching Students With Developmental Disabilities Daily Living Skills Using Point-of-View Modeling Plus Video Prompting With Error Correction . Focus Autism Other Dev Disabl, $30,195-207$.

4. Hamidreza Vatankhah, D. D. (2013). The effectiveness of communication skills training on selfconcept, self-esteem and assertiveness of female students in guidance school in Rasht . Social and Behavioral Sciences, 84, $885-889$.

5. Hitchcock, C. H. (2003). Video Self-Modeling Intervention in School-Based Settings A Review. Remedial and Special Education, 24 , 36-45.

6. Mohamad Sattar Rasula, . R. (2013). Graduate Employability For Manufacturing Industry . Social and Behavioral Sciences 102, 242-250.

7. Önalan AkfÕrat, F. (2004). Influence of Creative Drma on development of social skills of hearing- $\quad$ impaired people. Unpublished Doctorate Thesis. Ankara Üniversitesi. Institute for Social Sciences. Ankara.

8. Rosenthal, T. L., \& Zimmerman, B. J. (1978). Social learning and cognition. New York: Academic Press.

9. Savanee Sermsuk, D. T. (2014 ). Employment Conditions and Essential Employability Skills Required by Employers for Secondary School Graduate. Social and Behavioral Sciences, $116,1848-1854$.

10. Spence, S.H. (2003). Social Skills Training with Children andYoung People:Theory, Evidence and Practice. Child and Adolescent Mental Health Volume, 8, 84-96

11. Schlichting, K. A. (2004). A Self-Modeling Intervention for High School Students with Public Speaking Anxiety. Journal of Applied School Psychology ,20, 47-60.

12. Velayudhan, A., \& Palanisamy, V. (2015). Social skills on Percived Employability among Rural Yoth: Coimbatore District. In U. R. Mahadevan, Youth Developoment Emerging Perspective (pp. 57- 66). New Delhi: Shipra Publications.

13. Vygotsky, L.S. (1978). Mind and society: The development of higher mental processes. Cambridge, MA: Harvard University Press.

14. Yorke, M. (2004) Employability in higher education: what it is - what it is not. (York, Generic Centre, Learning and Teaching Support Network). http:// www.ltsn. ac.uk/genericcentre/index.asp?docid= 18968 . 